\title{
FAZENDO GUANXI: DÁDIVAS, ETIQUETAS E EMOÇÕES NA ECONOMIA DA CHINA PÓS-MAO'
}

Rosana Pinheiro-Machado

\section{Introdução}

Mesmo tendo se passado três décadas da abertura econômica (1979-2009¹), que pôs fim à era Mao, a discussão acerca do "espírito" do capitalismo chinês ainda suscita muitas polêmicas. Isto, contudo, não se deve exclusivamente à nebulosa interseção da ideologia estatal socialista com a economia de mercado, mas principalmente ao questionamento da persistência da prática do guanxi - laços e conexões pessoais — no sistema econômico.

O debate contemporâneo sobre o tema tem abordado a importância do guanxi em face de um sistema econômico que caminha em direção a uma suposta racionalidade das ações burocráticas e mercantis. Nesta perspectiva, a "teoria da transição" entende que a passagem do sistema socialista redistributivo para o capitalismo irá extinguir naturalmente a micropolítica dos laços pessoais (Guthrie 2002; Nee 1989, 1992). Noutra posição, como a sustentada neste artigo, entende-se que não existe um mercado ideal, pois ele é sempre imperfeito e inacabado e, portanto, o guanxi surge como aparato moral que preenche suas lacunas (Wank 1996, 2002). Trata-se de um componente emocional que, concomitantemente, responde e se alia a um novo sistema econômico, o qual introduz valores ocidentais baseados na legalização e no individualismo, por exemplo. Assim, o guanxi é entendido aqui como parte estruturante do mercado moderno e não como um vestígio arcaico que tende a desaparecer.

O objetivo deste artigo é discutir um processo social amplo - a renovada importância do guanxi na engrenagem da economia de mercado chinesa a partir de um enfoque microscópico, baseado em minha experiência etnográfica. Se é notório o fato de que laços pessoais desempenham suma importância na conformação do mercado, na realocação de empregos e na prosperidade dos negócios em diversas sociedades (ver Granovetter 1973, 1974), o que se discute aqui é a intensidade, a particularidade e a resistência dessas características na China. Existe um "capitalismo chinês" (ou 
restringimo-nos apenas a capitalismo na China)? Se sim, qual é, então, a sua especificidade? Esta questão será desenvolvida adiante, mas antecipo o argumento de que é possível pensar uma expressão sui generis do capitalismo, que é justamente a indigenização do mercado a partir da incorporação das regras locais do guanxi.

Embora o campo teórico sobre o guanxi seja extremamente extenso e, por isso, pareça andar em círculos tocando em velhas questões (se persiste ou não persiste; se é uma prática pragmática ou afetiva; se pertence à cultura chinesa desde longa data ou é um fato recente etc.), a relevância de se repensar o tema se renova, especialmente em face da pujança da presença chinesa na economia global. Minha contribuição neste trabalho é mostrar como redes pessoais são operantes no sistema econômico a partir do ponto de vista da intersubjetividade etnográfica, já que a única forma de estudar este tema - na condição de mulher e estrangeira - era fazendo, eu mesma, guanxi. Inserindo-me em redes, estabelecendo-as conforme mandam as regras e tornando-me igualmente agente econômico, participei de tradicionais cerimoniais de dádivas que se atualizam na economia atual. Este enfoque intersubjetivo contribui para uma análise que procura romper com alguns dualismos formados ao longo da história da antropologia, buscando mostrar a tênue linha que separa a vida pública da privada, a racionalidade da intimidade, o ganho material do imaterial, o interesse do sentimento, a dádiva da mercadoria (cf. Appadurai 2006; Bourdieu 2001; Zelizer 2001, 2005).

Por fim, ao longo do texto que segue, três camadas analíticas se sobrepõem. A primeira refere-se ao meu próprio processo de formação de guanxi; a segunda, à dinâmica das redes entre os informantes entre si e, a última, à importância do relacionamento social em tempos de abertura econômica. O artigo está dividido em cinco seções. Na primeira, teço um breve comentário sobre o universo empírico no qual se passou a etnografia. Posteriormente, discuto o tema do "espírito do capitalismo chinês", introduzido nas ciências sociais por Max Weber. Na terceira, discorro sobre algumas características do guanxi destacadas no debate teórico contemporâneo, para, então, nas duas seções subsequentes, narrar e analisar meu processo etnográfico de formação de conexões, bem como dos informantes entre si. Apresento três eventos de pesquisa que evidenciam os mecanismos de formação e manutenção do guanxi na China atual.

\section{Nota sobre o universo empírico}

A abertura econômica, iniciada no fim da década de 1970 sob o comando de Deng Xiaoping — sucessor de Mao Tse-tung — pôs em prática um modelo 
de industrialização acelerada, propiciando que a província de Guangdong, localizada ao sul, despontasse como âncora do crescimento econômico do país, devido ao fato de concentrar as principais Zonas Econômicas Especiais (ZEE). As mudanças acarretadas pela abertura mercantil fizeram com que vilarejos se tornassem metrópoles em menos de 30 anos, como é o caso de Shenzhen cidade onde construí a etnografia sobre a qual este artigo se fundamenta.

As ZEE possuem carga tributária mais baixa e condições autônomas de mercado. O objetivo é atrair investimento externo e interno através do oferecimento de taxas reduzidas. Shenzhen, que faz limite com Hong Kong, é a mais importante ZEE do país. Nesta cidade, de aproximadamente 11 milhões de habitantes, estão instaladas 144 das 500 multinacionais que existem no mundo. Assim como em Xangai, nela vivem as novas elites empresariais do país, bem como estrangeiros que representam empresas de diversos países que decidiram estabelecer negócios com a China. A cidade é integrante da região conhecida como Delta do Rio da Pérola (ou Grande Delta) - área notável economicamente, uma vez que concentra um terço de toda a indústria nacional e um contingente populacional de 48 milhões de habitantes. ${ }^{2}$

Devido a estas características, a província de Guangdong é uma das regióes mais urbanizadas, modernas e globalizadas da China. Trata-se de um universo em que os novos valores relativos ao consumo, ao lucro privado, à autonomia individual e ao culto à riqueza (Davis 2000; Ong \& Li 2008) aparecem de forma muito mais intensa do que em outras províncias. Realizei trabalho de campo nessa área, especialmente em Shenzhen, por oito meses, entre os anos de 2006 e 2007, com o propósito de estudar redes mercantis envolvidas na pequena e média indústria do país.

Naquele período, visitei estabelecimentos comerciais, como lojas e atacados, bem como fábricas cujos proprietários integravam o rico leque de capital social de minha intérprete, Feifei ${ }_{1}^{3}$ uma chinesa de 34 anos nascida em Beijing, mas que há dez anos ensina mandarim em Hong Kong. Como tem sido comum a muitos etnógrafos que realizam pesquisa de campo em país de língua estrangeira, minha intérprete passou a ser também minha informante-chave, na medida em que ela participava de uma extensa rede social, que se relacionava diretamente com meu objeto de estudo.

\section{Do espírito do capitalismo chinês}

Diante da abertura econômica promovida na era Deng e de todas as suas implicações sociais, renova-se a necessidade de problematizar uma questão que, desde longa data, paira sobre o contexto da antropologia/sociologia da 
China: a especificidade do capitalismo chinês e o alto grau de personificação de sua burocracia. Talvez como em nenhum outro período da história, o debate iniciado por Max Weber no final do século XIX — em As religiões da China, obra escrita logo após Ética protestante e o espírito do capitalismo - tenha sido tão atual e pertinente. Em suma, discute-se se as relações pessoais prosperam ou desencorajam o desenvolvimento do capitalismo chinês.

Weber (1968) comparou a ética calvinista e confucionista e inferiu que ambas possuem paralelos no que diz respeito a uma forma de conduta individual que tem como consequência a acumulação de capital. No entanto, apesar de as duas éticas serem semelhantes no alto grau de racionalização dos sujeitos, o calvinismo produziria, alimentaria o espírito do capitalismo, enquanto o confucionismo o desencorajaria. Na primeira parte da obra, ele analisa as condições "materiais" da China (formação de cidades, leis, família, estrutura da burocracia etc.) e, nesses aspectos, encontra características distintas, mas algumas bem próximas às dos países europeus onde o capitalismo se desenvolveu sob a ética protestante. Logo, a barreira ao desenvolvimento do capitalismo estaria mais fortemente presente na mentalidade chinesa ou no "Tao", princípio que valoriza a harmonia e o equilíbrio do universo. Existiria, assim, uma tendência ao conformismo, à aceitação do mundo tal qual ele é. Além disso, o legado confucionista tolera o misticismo, aprecia a hierarquia, a aceitação da ordem, a polidez e, principalmente, a importância dos laços familiares e da ancestralidade. Em consequência disto, o questionamento e a capacidade de transformação, imprescindíveis ao capitalismo, estariam prejudicados. Predominariam, portanto, traços tradicionais no lugar de modernos.

O alto nível de reciprocidade no interior das redes e a ajuda em casos de adversidade constituem fatores que não favoreceriam, por exemplo, o pagamento de dívidas. Os negócios no interior de esferas "familiares" seguem as "características de paternalismo, pessoalidade, oportunismo, flexibilidade, diferentemente do padrão ocidental de profissionalização e burocratização" (Redding 1993:03). Todos estes aspectos, então, se colocariam como barreiras para o desenvolvimento do capitalismo pleno.

Hoje, no entanto, ao contrário daquela previsão, há um reconhecimento acerca do papel das redes pessoais para o desenvolvimento de certos setores produtivos chineses. Além disso, Randall Collins pontua que a teoria de Weber deve servir como um ponto de partida para o entendimento do capitalismo, mas ela é insuficiente, pois precisa ser complementada com novas análises. Isto porque, na realidade, não foi só o calvinismo que propiciou o desenvolvimento do capitalismo, já que "há outros exemplos nos quais nós podemos ver asceticismo motivado religiosamente conjugado com produtividade econômica" (1999:76). 
Este tema, dos laços pessoais e do empreendedorismo chinês, foi o nó inicial de uma longa e heterogênea discussão, voltada para a especificidade dos negócios chineses dentro e fora do território nacional (ver Chan 2000; Delaune 1998; Freedman 1967; Gipouloux 2000; MaMung 2000; Mackie 2000; Oxfeld 1992; Redding 1993; Schak 2000; Tan 2004; Wu 2000, entre muitos outros). Boa parte dessa literatura está inserida no campo de discussão sobre as comunidades chinesas ultramar. Isto explica por que, muito antes de o capitalismo existir na China, já se discutia longamente sobre ele. Afinal, a população chinesa além-mar tem sido caracterizada, há décadas, pela atividade comercial, empreendedorismo e negócios em família. Somente a partir da década de 80 , é que este tema vai se voltar para a própria China, quando o país coloca em prática as reformas político-econômicas, sendo uma delas a própria cooptação de investimentos da população da diáspora. ${ }^{4}$

Voltando à questão exposta no início deste artigo sobre a possibilidade de existir um "espírito do capitalismo chinês", entendo que esse espírito, em parte, é a própria ética confucionista, conforme já defendi alhures (Pinheiro-Machado 2007). Todavia, diante do debate contemporâneo, creio que a noção de guanxi seja mais elucidativa do que a de confucionismo, na medida em que a segunda está contida na primeira. No que concerne à atualização desse legado, destaca-se a lealdade como categoria central que sustenta as conexões. Confiança, fluxo de informações, "espírito" de harmonia e obrigatoriedade dos laços também são alguns dos aspectos que propiciariam o desenvolvimento dos negócios, criando um ambiente seguro de investimento e fluxo de capital.

Essas redes de negócio podem acontecer com múltiplos atores econômicos. Na República Popular da China, especialmente, o capitalismo teve de se ajustar a características extremamente arraigadas no sistema cultural chinês, como a centralidade do poder nos agentes do Estado e a força da burocracia que se estende a todas as áreas da vida social chinesa. "[Na China] existe uma estrutura na qual qualquer coisa depende do favor oficial" (Redding 1993:232). Além disso, "a China é dependente da 'oficialização personalizada'. Sem usar o guanxi, nada significativo acontece. [...] O Guanxi é tão importante quanto sempre foi" (ibidem:231-235). Ao passo que o país se abre para a economia de mercado, o sistema estatal conserva essas práticas, as quais tiveram seu auge durante a Revolução Cultural, quando os guardas vermelhos e os líderes de comuna se alastravam por toda a nação, detendo um grande poder sobre as comunidades. Bens escassos eram disponibilizados aos camponeses em troca de lealdade aos agentes do Estado (ver Gold 1985; Oi 1985; Vogel 1965; Wank 2002). 
A abertura para a economia de mercado, enfim, chama a atenção para práticas informais em sentido lato, entrelaçando um alto nível de personificação das instituições políticas e econômicas através do contato face a face de seus agentes - empresários, autoridades do Estado e tecnocratas — que, desde a Reforma, constituem as novas elites financeiras da China (Li 2000). Observar o mecanismo do guanxi ajuda a compreender como, diante de instituições econômicas "fracas", foi possível um crescimento e enriquecimento extraordinário de diversos setores da nova China (Wu 2000), caracterizando um processo de institucionalização do guanxi na era pós-Mao (Wank 1996).

\section{Aproximando-se do guanxi}

Como eu estava no campo para estudar redes mercantis, sabia que, enquanto mulher e estrangeira, as dificuldades não seriam poucas, na medida em que boa parte do sistema econômico de Guangdong envolve práticas informais, as quais são compartilhadas com um seleto grupo de relações pessoais. Logo, para entender o guanxi, eu teria de criar guanxi. Como dizem os nativos, os laços se formam e se cultivam com vistas a algum propósito a longo prazo.

Estudando-os, tive de estabelecer minhas próprias relações e, assim, tornei-me igualmente sujeito da pesquisa, na medida em que participava intensamente da realidade que observava. Isto exigiu uma vivência singular em momentos cerimoniais: participar de um banquete de almoço permeado de regras e nele embriagar-me nos ganbei (brinde tradicional chinês), ir a uma fábrica no interior do país durante a tarde, jantar ensopado de cachorro e carneiro à noite e terminar a jornada do dia numa casa de massagem junto com intérprete e informantes.

Chegar a este estágio da etnografia, todavia, não foi um processo rápido: por meses deparei-me apenas com portas e caras fechadas. Decidi, então, entrar numa escola de mandarim para fazer contatos. Eis que, em menos de uma semana, todo o quadro de inércia mudou. Feifei aceitou trabalhar como minha intérprete por um valor estipulado em horas. O intuito desse acerto era, mais do que traduzir em sentido estrito, mediar sistemas culturais distintos: apresentar-me a pessoas e levar-me a lugares-chave. Ela, imediatamente, acionou sua rede de relações sociais para que eu pudesse fazer entrevistas. Assim, ingressei no jogo das relações sociais chinesas, com suas regras e etiquetas, no momento em que eu e Feifei estabelecemos guanxi.

Em primeiro lugar, é importante dizer que o guanxi é uma categoria concomitantemente emic e etic. Em termos gerais, essa prática implica a formação de conexões pessoais diádicas, que pressupõem uma ética de 
obrigações. Segue o princípio da economia do dom — dar, receber e retribuir (Mauss 2003), com vistas à formação de redes sociais (guanxiwang). Alguns alegam que, embora muito se festeje em torno do conceito, ele nada mais é do que uma forma chinesa ou "um brilho orientalista para rede social", bem como "há uma tendência de ver, nos fenômenos chineses, mais do que eles realmente são" (Schak 2000). Assim, certas análises são acusadas de essencialistas (ou substantivistas nos termos da antropologia econômica), buscando no confucionismo um legado cultural e histórico para explicar o comportamento social chinês.

Indubitavelmente, esse sistema possui inúmeros paralelos com práticas presentes em todas as sociedades e, portanto, constitui-se em mais um exemplo de economia do dom (ver Yan 1996; Yang 1994), de rede social e de "laços fortes" (Guthrie 2002), de capital social (Smart 1993), de clientelismo (Gold 1985; Oi 1985; Wank 1996, 2002) e, até mesmo, do "jeitinho brasileiro". Todavia, também entendo que o guanxi extrapola todos esses conceitos por alimentar um rico campo semântico, por sua valorização altamente consciente, por se estender a diversas áreas da vida social e, finalmente, por manter uma ética afetiva e moral bastante complexa.

O guanxi manifesta-se em diversos contextos - na vida rural e urbana, na sociedade capitalista e comunista - metamorfoseando-se, mas mantendo uma matriz de significado. Seguindo as regras da reciprocidade, o guanxi deixa pessoas em débito através de negociações, geralmente entre duas pessoas de hierarquias diferentes. Todavia, não estamos diante de qualquer forma de relacionamento e de reciprocidade, mas de uma expressão muito particular e estrita, baseada em tratos de lealdades, moralidades, confiança, ajuda mútua e hierarquia. Tais tratos, que ocorrem através de códigos não escritos e de honra, devem seguir os princípios confucionistas e taoístas de harmonia, equilíbrio e ordem. Isto implica a necessidade de um tempo de construção e cultivo das relações. Por isso, a reciprocidade (bao) acontece através de uma etiqueta e de um ritual (li) contínuo; e o descumprimento do sistema de obrigações faz com que o receptor em débito perca prestígio (mianzi) (Chan 2000; Gold 1985; Gold et al. 2002; Gipoloux 2000; Hwang 1987; Jacobs 1979; Kipnis 1996, 1997; Redding 1993; Smart 1993; Wank 1996, 2000; Yan 1996; Yang 1994).

O guanxi mistura as dimensões instrumentais e sentimentais, dom e mercadoria, sendo baseado numa ética afetiva bastante forte. Assim como há um retorno pragmático esperado, advindo das relações de trocas, trata-se de sistema baseado em emoções, as quais variam entre renqing (sentimento) e ganqing (afeição). Além disso, para que o relacionamento aconteça, é imprescindível a existência de uma base de relacionamento (guanxi-base), 
que é uma identificação comum ou um passado compartilhado. A união de pessoas ao longo da vida é uma questão de destino (yuanfen). As bases são diversas, mas há uma ênfase sobre a filiação regional muito forte. As principais são a família (jia), o parentesco (qingqi) e todas as suas formas estendidas; o local de origem/raiz/dialeto/comunidade/vizinhança (tongxiang); o local de trabalho (danwei), os colegas de escola (tongxue); os colegas de associações, negócios etc. (tongshi), e a relação professor-aluno (laoshi-xueshang). Diante da inexistência de uma base, as pessoas forjam um relacionamento - la guanxi - ato muito comum entre empresários estrangeiros que precisam criar vínculos na China para realizar negócios (Gold 1985; Gold et al. 2002; Hwang 1987; Jacobs 1979; Kipnis 1996, 1997; Smart 1993; Wank 1996, 2000; Yan 1996; Yang 1994).

Esse sistema de conexões manifesta-se através de cerimoniais e possui uma etiqueta estrita. O Guanxi deve ser estabelecido e nutrido ao longo do tempo, o que é considerado uma arte: a arte do relacionamento social. Guanxixue significa guanxilogia: uma expressão popular que se refere à arte de saber aplicar os caminhos informais (Yang 1994).

No que diz respeito ao guanxi no âmbito dos negócios em espaços urbanos e industrializados, este passou a ser visto como uma forma cínica de relacionamento que, enquanto um poder invisível, procura obter ganhos "pela porta de trás", colocando-se como uma alternativa à falta de base legal ou às instituições econômicas "fracas". Em tempos de economia de mercado, os banquetes continuam sendo acionados como a mais nobre dádiva, sendo uma forma de comoditização do guanxi (Yang 1994). Quando essa prática é planejada para estabelecer conexões, envolve um nível maior de rituais e etiquetas do que comumente exige. Nesses casos, não são eventos meramente sociais e, geralmente, envolvem trocas econômicas e políticas. Foi entre regras, bebidas e comidas que construí minha etnografia junto à minha intérprete e sua rede de empresários.

\section{Fazendo guanxi: três eventos etnográficos}

\section{Entrando em campo: a vida social de jovens empreendedores}

O controle sobre o trabalho de campo, em meu ponto de vista, significava um planejamento das ações e do tempo: faria uma entrevista ou alguma observação no dia e na hora marcada e, então, iria embora. Neste raciocínio, havia lugar para imprevistos e prolongamentos, mas sempre dentro de uma margem "prevista". Todavia, minha primeira lição de trabalho de campo foi 
compreender que o estabelecimento de relações sociais tinha um tempo próprio, tempo este sempre muito mais longo do que eu poderia imaginar.

Meu contato inicial com informantes deu-se com jovens comerciantes de Shenzhen, que conheci em virtude de uma festa do Ano Novo ocidental da qual Feifei me convidara a participar. Com os seus amigos e a sua prima Kate, passei a noite até o amanhecer em uma boate. Aos poucos, ia entendendo que aquele evento tinha certas regras, como beber (foram pedidos aproximadamente dez litros de chá com uísque), aceitar o oferecimento de bebidas do grupo masculino e, posteriormente, fazer uma refeição num restaurante, também ofertada. Além disso, cada informante homem fumou aproximadamente duas carteiras de cigarro ao longo da noite.

Cansar ou querer ir embora mais cedo - atos esperados devido aos excessos da noite - eram tarefas inviáveis e consideradas mal-educadas, já que a sociabilidade tinha uma sequência de cultivo e de desfrute. A pressa era falta de educação; e o tempo, uma dimensão fundamental. Esta foi a primeira regra de iniciação.

No restaurante, às 5 da manhã, enquanto comíamos um "churrasco" chinês de porco, gado, frango e rã, fui conhecendo os quatro rapazes que nos acompanhavam. Um deles era Ian, 26 anos, hongkonês, mas criado na Austrália. Feifei levara-o junto para a festa e ele, assim como eu, também havia sido apresentado para os outros rapazes naquela noite. Quando eu soube que os outros três jovens eram comerciantes do ramo da pequena e média indústria do país (o que eu desejava estudar), fiquei muito entusiasmada. Perguntava se era possível marcarmos uma entrevista, mas o assunto era desviado o tempo todo. Visivelmente, eles não queriam falar sobre o trabalho comigo — outra regra - pois perguntar sobre ocupação pode ser considerado um ato invasivo entre pessoas que não se conhecem. Na semana seguinte, pedi à Feifei que mediasse um encontro de entrevista com os jovens empreendedores. Ela traduziria para mim e receberia, para tanto, 500 yuan.

Para economizar o tempo de jovens que vivem sob a lógica da produtividade em que "tempo é dinheiro", tratava-se de uma entrevista coletiva, marcada para as 19 horas num lugar qualquer em Shenzhen. Pelas minhas contas, à meia-noite eu estaria de volta a Hong Kong, onde eu dormiria, até porque eles diziam que "não tinham muito tempo para isso". Durante a semana, Feifei passou em minha casa para irmos a uma loja da redondeza. Ela explicou-me que seria muito educado de minha parte levar um presente para Hui (o principal entrevistado), já que ele se disponibilizara a nos conceder entrevista e esta aconteceria durante um jantar que ele desejava nos oferecer.

Às 15 horas de um sábado encontrei-me com Feifei no lugar marcado, na estação de Tsim Sha Tsui, de Hong Kong. Para minha surpresa, noutra 
estação, Ian entrou no trem - ele ia junto para a entrevista. Fiquei um pouco desconfortável com a ideia, pois Ian não seria entrevistado e, portanto, juntava-se a nós como quem ia a uma festa. Meu foco, estabelecido num contrato oral cujo pagamento se deu adiantado, não era participar de um evento social, mas entender um pouco mais sobre a vida de jovens empreendedores chineses. Feifei e eu deveríamos cumprir o combinado: tradução de um lado e pagamento de outro. Contudo, para aumentar meu descontentamento (e meu entendimento de que ela descumprira nosso acordo), chegamos à alfândega e lá estava a prima de Feifei nos esperando, arrumada e maquiada como quem iria a uma festa: ela queria começar um relacionamento amoroso com um dos rapazes que eu ia entrevistar. Assim, eu percebia que a situação escapava de meu controle. Minha entrevista (paga) era apenas uma desculpa para um evento social de Feifei e seus afetos.

Mais tarde nos encontramos todos num restaurante tradicional de Shenzhen. Hui ofereceu o que tinha de melhor e agraciou-me com carnes que eu apreciava, como porco, gado e frango. Foram servidos vinhos especiais e, assim, brindamos muito. Ele também pedia uma série de especiarias para que eu experimentasse, já que o restaurante possuía a cozinha de todas as regiões da China. Todos me ensinavam os hábitos adequados à mesa cantonesa, como o mais importante, que é lavar as tigelas com o chá da mesa. De vez em quando, em meio ao burburinho, Feifei dizia: "Quer fazer tuas perguntas, então faça!". Eu explicava que havia um roteiro e que naquele local barulhento seria impossível desenvolver qualquer conversa. Além disso, ninguém parecia estar interessado na entrevista.

Fomos então para um café perto do restaurante, onde Hui pediu sorvetes, tortas e outras guloseimas. Naquele lugar havia uma música alta e um ambiente de boate. Todos os entrevistados estavam acompanhados de garotas e não pareciam nem um pouco dispostos a falar. Sentia-me inconveniente. Eles estavam definitivamente contrariados e respondiam qualquer coisa em meio à barulheira. Hui, sensibilizado com o presente que ganhou e com minha insatisfação, era o único que se preocupava em responder, ao passo que Feifei não traduzia o que ele dizia. Passou-se mais de uma hora de muito esforço. Para eles, tudo estava dentro do normal. Para mim, uma calamidade. A essas alturas, já era mais de meia-noite e eu dava adeus ao meu trem de volta para Hong Kong.

O segundo jovem entrevistado, Max, estava visivelmente nervoso e começou a suar frio durante minhas perguntas iniciais. Fiquei constrangida de causar aquele desconforto. A prima de Feifei, Kate, ficou muito enciumada com a situação e não parava de abraçá-lo enquanto eu o entrevistava. Ele, por seu lado, queria se livrar daquele momento para dar atenção a ela. Eu 
chamava Feifei para que traduzisse. Ela, então, sabendo que o rapaz sabia algumas palavras em inglês, dirigiu-se a ele e disse: "Vamos lá! Pratique seu inglês!". E virou para o lado, voltando a beijar Ian. Sentindo que nada dava certo, parei de insistir. O terceiro rapaz, John, sobrara nas trocas afetivas e foi embora. Àquelas alturas, eu já havia entendido que não havia lugar para entrevista e já sem tolerância, vontade ou força, desisti de seguir tentando em vão. Era a hora de ir para a casa.

Depois das duas sessões prolongadas de comidas e bebidas, agradeci e disse que então iria embora. Percebi um murmurinho generalizado no ar, até que Feifei me disse que aquilo não seria uma atitude adequada, já que eles haviam se colocado à disposição para falar e, principalmente, a pagar o jantar. Por educação, eu deveria, portanto, acompanhá-los ao longo da noite. Fiquei, então, até as 6 da manhã em um karaokê, ouvindo e, por vezes, balbuciando algumas letras de músicas chinesas que eu conhecia. Muitos ganbei (brinde tradicional chinês) se passaram. Eles repetiram o hábito de pedir uísque e misturar com chá gelado. Como estrangeira, sempre me era exigido que experimentasse todas as bebidas. Tudo o que eu tentava recusar soava como falta de educação, vinda de alguém incapaz de desfrutar daqueles momentos rituais. O resultado dos ganbei foi eu ter de ser levada para a casa, já com sol raiando. Feifei cobrou o valor integral de duas horas de entrevista, embora não tenha traduzido quase nada e, além disso, foi agraciada com um jantar.

Embora o evento tenha tido parcos resultados em relação a seu objetivo inicial, desde a compra da camisa barata até a embriaguez no final da noite, foi repleto de situações paradigmáticas do universo cotidiano do guanxi e de suas relações de poder. Os presentes, a comilança, a bebedeira, o tempo de negociação e de compartilhamento de um evento social eram algumas das regras e das etiquetas básicas. Além disso, apesar de as entrevistas terem sido, em si, frustrantes, poucas coisas seriam tão ilustrativas acerca do que significa o sucesso entre jovens empresários. Havia ali uma ritualização em torno da própria condição, já que sabiam, previamente, que meu objetivo era entender como sujeitos tão jovens, que tinham vindo da zona rural e cujas famílias ainda trabalhavam no campo, podiam ter sido tão bem-sucedidos rapidamente. O que havia acontecido com a China que propiciara isso? Para explicar o fato, poucas palavras, mas antes, o oferecimento de bebidas e comidas, sempre levado ao esbanjamento, acompanhado de muito cigarro e demonstrações públicas de poder e masculinidade

No que se refere à dimensão cultural dos negócios, do meu ponto de vista, eu e Feifei tínhamos um contrato. Ela marcaria as entrevistas, nós nos reuniríamos, teríamos algum evento social introdutório. Eu pergunto, eles res- 
pondem, ela traduz. Eu pago, ela recebe. E caso surgisse convite para seguir no karaokê - algo que já estava fora do contratado - esse convite poderia ser aceito ou negado, dependendo da vontade. Sem primas ou namorados interferindo. No acordo, eu separava, assim, vida pública de privada.

Para Feifei e seus amigos, tudo era diferente. Os limites entre o afetivo e os negócios pouco importavam. A entrevista passava por uma negociação humana que extrapolava a frieza do contrato de compra e venda de um serviço. Tinha um tempo e regras a cumprir. Se eu me senti enganada pagando por uma tradução que não existiu, Feifei achava que tudo tinha transcorrido dentro da maior normalidade; era impossível não passar pelo jantar, tampouco não ir ao karaokê. Quando eu quis embora, ela advertiu-me um tanto brava: "Não é assim que funcionam as coisas!". Esta frase e os olhares recriminadores dos outros me davam o tom do universo em que me inseria.

Na China, os negócios de qualquer natureza passam pela confiança e, para alcançá-la, deve-se cultivá-la. Estabelecer guanxi exige calma e cuidado. Seja a contratação de uma entrevista/tradução, seja a contratação de serviço por parte de uma empresa transnacional, o princípio é o mesmo: não é a impessoalidade que impera nessa esfera, mas o desfrute das relações humanas.

\section{Entre autoridades e empresários}

Cheguei à China com um objetivo claro: conhecer fábricas dos produtos que estudava, a saber, a indústria de pirataria. Passados os primeiros meses, percebi que se tratava de uma tarefa quase impossível. Era hora de acionar Feifei novamente. Ela lembrou que conhecia um policial de Shenzhen que podia ajudar.

O pai de Feifei é um general aposentado do exército chinês. Ele mora em Beijing, mas é oriundo de Huibei. No passado, ajudou um jovem e ambicioso rapaz que chegara de sua cidade natal para trabalhar na capital. Shenzhen estava rapidamente passando de uma pequena vila para uma das cidades mais ricas da China e lá estavam as melhores oportunidades de trabalho. $\mathrm{O}$ general, ligado ao jovem graças ao vínculo de raízes regionais (tongxiang), acionou seus contatos em Guangzhou (capital de Guangdong) e conseguiu que o rapaz trabalhasse na polícia de Shenzhen. Gao, hoje policial de alto posto, carrega uma dívida de gratidão com o pai de Feifei.

Gao gostaria de casar com Feifei. A família dela também possui a mesma vontade, mas ela se recusava e preferia viver como solteira em Hong Kong com seu filho adotivo de 9 anos. Feifei, através de seu charme, acionou o policial para que eu conseguisse conhecer uma fábrica, uma vez que os 
policiais na China contemporânea, bem como as demais autoridades locais, possuem grande poder sobre o seu universo, justamente graças a esse sistema econômico e social cuja engrenagem está entrelaçada a relações pessoais.

Para que eu cumprisse a saída de campo tal como planejava, teríamos que deixar Hong Kong de manhã para chegar a Shenzhen ao meio-dia e almoçar com o policial, o qual nos levaria a alguma fábrica. Feifei decidiu sair no dia anterior ao meio-dia (24 horas antes), pois queria encontrar um conhecido em Macau. Tarde da madrugada fomos para Zhuhai, outra Zona Econômica Especial, na fronteira com Macau. Dormimos pouquíssimas horas, pois Feifei queria aproveitar tudo. $\mathrm{O}$ dia seguinte era especial para mim pois, além de entrevistar um policial, eu visitaria uma fábrica. Queria estar com energia e com uma boa aparência para aquele momento que eu considerava formal.

Acordamos muito cedo e pegamos um barco para Shenzhen. Em menos de 24 horas fizemos uma ronda por Hong Kong, Macau, Zhuhai, Shenzhen, o que me fez chegar muito cansada para o almoço. O policial, levando muito a sério o pedido de Feifei, apanhou-nos no porto com seu novíssimo carro Honda que, por dentro, portava enfeites com a face de Mao Tse-tung. Ele convidou-nos para almoçar. Antes, porém, fez uma visita a um conhecido que trabalhava no mais luxuoso prédio empresarial de Shenzhen. Tratava-se de um dos mais famosos empresários da região, Liu, dono de uma multinacional chinesa de fabricação de papéis. Gao levou chá de presente para ele, que lhe retribuiu com um conjunto de porcelana de valor incalculável. Liu nos oferecia o chá com todas as regras que o cerimonial exige, algumas delas peculiares à região cantonesa, além de servir frutas secas. Gao disse-me que estávamos ali para que eu conhecesse um empresário, já que eu estudava, grosso modo, a economia da China. Minha vida acadêmica rotineira era motivo de exagero por parte de Feifei que, naquele circuito, dizia com sorriso doce e ingênuo: "Meu pai é general, eu serei Mestre e ela é boshi (doutora) e já escreveu muitos livros no Brasil". Ela também dizia que minha família era muito importante e que meu pai era empresário, político e tudo mais que ela era capaz de imaginar.

Depois de o policial receber o presente raro que ganhou na visita, fomos almoçar e, para tal evento, Gao já havia convidado mais outros dois empresários, também renomados na região, Shang e Chang. Liu tinha reservado uma sala no interior de um dos melhores restaurantes de Shenzhen. Na realidade, ele era proprietário daquela sala exclusiva no restaurante, uma vez que grandes empresas costumam possuir seus próprios estabelecimentos, onde realizam suas negociações (Wank 1996).

Desse modo, banquetes em ocasiões especiais são feitos em salas reservadas - pensadas como extensão da casa - nas quais há uma cozinha 
própria e algumas pessoas para servir exclusivamente. A mesa, na maioria dos casos, é redonda. Naquele evento, não conseguia esconder meu deslumbramento e fazia comentários e elogios no intuito de ser sociável, mas Feifei chutava-me por debaixo da mesa, alertando que eu deveria fingir que tudo aquilo era muito natural, para não denunciar que eu não tinha background, como ela dizia.

Chang e Shang (o dono da fábrica de recipientes de papel e o importador de vinhos, respectivamente) levaram também presentes finos para o policial. Um deles, com ar e sorriso ingênuos, dizia-me: "Relacionamento é muito importante na China, policiais são pessoas muito importantes, nunca sabemos quando iremos precisar da ajuda de um, é importante cultivar essa amizade". E assim, o policial encheu o porta-malas do carro de relíquias e, além disso, ofereceu, a mim e a Feifei, um almoço de luxo pago por outra pessoa. Não havia naqueles gestos qualquer sentido de corrupção, qualquer pessoa era capaz de entender que se tratava de um ato rotineiro de dádivas dentro de um cerimonial tradicional, que são os banquetes. Policiais deveriam ser bem tratados por serem úteis de diversas formas.

Naquele almoço comemos passarinho, crocodilo, carne de gado (uma picanha ao molho madeira em minha homenagem) e lagosta, que é o prato típico de Guangdong, além de inúmeras especiarias cantonesas e chinesas, as quais eu provava sob os olhos atentos de todas as pessoas que, paradas, esperavam-me dar o veredicto. Assim, sucedia-se com tudo que chegava à mesa. Um dos empresários levou vinho canadense de sua importadora. As falas dos homens, durante aquele acontecimento, remetiam pouco ao mundo dos negócios. O assunto preferido era sexo, contando piadas sobre o tamanho do pênis dos japoneses, o que, indiretamente, ressaltava a virilidade deles próprios. Sexualidade, poder e dinheiro, na realidade, eram o que eles estavam ritualizando.

Como em nenhuma outra situação semelhante, fui a personagem principal do guanbei - ato ritual de passagem de agregação do estrangeiro (Van Gennep 1978). Tomei cerca de dez copos de vinho tinto, sob as palmas dos homens que, ansiosamente, esperavam ver o copo vazio. Nesses momentos, não se pode fraquejar, beber significa empinar um copo sem pausas. Eu pedia para parar, mas era em vão. Graças a isso - aliado ao fato de eu estar muito concentrada e de olhos sempre muito abertos tentando entender as conversas, as trocas de presentes e as rotineiras demonstrações de masculinidade e sucesso através de falas e gestos significativos presentes naquela ocasião comecei a ter um "tique nervoso" na testa e meu rosto ficou roxo. Os olhos bem abertos e a testa franzida (expressão de quem tenta prestar atenção em tudo o que é dito) pareciam ter congelado para sempre. Eu tinha chegado ao 
limite de quem, para visitar uma fábrica, tinha saído de casa 24 horas antes, praticamente sem dormir e estava num almoço que já se arrastava por três horas. A causa principal de minha súbita reação corporal foi, além da bebida, o imenso autocontrole que eu tinha sobre minha fala, meus gestos e atitudes, fruto do meu temor de não dominar os códigos daquele evento.

$\mathrm{Na}$ condição de iniciante aos banquetes empresariais chineses, eu queria agir de acordo com a etiqueta, pois isto é considerado uma virtude. No que se refere aos hábitos à mesa, as regras são extremamente antigas e variam de região para região. Num banquete, tudo é altamente posicionado e regrado. Evidentemente existem muitas regras, algumas levadas a sério, outras flexibilizadas, dependendo da ocasião. No meu caso, embora os integrantes do banquete achassem "engraçada" a forma desajeitada com que eu me comportava, eu não conseguia relaxar, até porque minhas falas eram controladas pelo chute que recebia de Feifei por debaixo da mesa.

O meu "tique nervoso" foi o estopim para terminar o infindável almoço, o qual eu tinha agradecido com um brinde, levantando o copo e dizendo a frase recomendada: "Xiexie ni men! Wo hen gaoxing, zhe ge wufan hen hao!" (Obrigada a todos, eu estou muito feliz, este almoço está muito bom). Gao disse a Feifei que tinha que trabalhar à tarde e que, portanto, outra pessoa nos acompanharia até uma fábrica. Ele apontou para Shang, o importador de vinhos, e ordenou: "Leve-as onde elas quiserem!". E ele, pronta e sorridentemente, aceitou. Peguei meus pertences que tinha deixado no carro de Gao e ele, por seu turno, encheu o porta-malas com os presentes raros que ganhou naquele almoço. Ao mesmo tempo, lembrou de dar algo a Feifei: outra especialidade de chá, cultivado há muitos anos. Gao pediu que ela não esquecesse de entregar ao seu pai quando fosse a Beijing para as festividades do Ano Novo chinês.

No carro de Shang, eu me deitei, ainda com profundo mal-estar. Viajamos, então, para a cidade de Longguan para visitar a fábrica de Xin. Trata-se de um jovem empreendedor que, com seus então 26 anos, já havia enriquecido rapidamente. Por algumas horas, visitei todas as instalações (quartos, refeitório etc.), analisei balancetes, conversei com empregados que, num feriado, trabalhavam até o anoitecer. Soube que ali trabalhadores recebiam cerca de RMB 540 (valor muito abaixo do salário mínimo da região, que gira em torno de RMB 800), e que ali, também, trabalhavam crianças. Xin falou-me sem constrangimento que, assim como fazia os produtos de uma marca, fazia cópias desta mesma marca para outros clientes. Essa liberdade, contudo, não era à toa, mas porque eu estava acompanhada de Shang, a quem o proprietário conhecia desde criança, quando viviam no interior da província de Fujian. Shang foi primeiro para Shenzhen e ajudou o antigo 
conhecido a encontrar casa para morar e, posteriormente, um loteamento para alugar, além do favorecimento através de contatos com o poder local, sem o qual qualquer negócio não se viabiliza. Em menos de três anos, com o suporte do guanxi dos amigos e da família, o jovem de Fujian passou a lucrar, para si, 1 milhão de yan por ano.

A noite encerrou-se num restaurante popular de rua, em que comemos ensopado de carne de cachorro e carneiro, sentados no chão, a céu aberto. Cabe ressaltar que Feifei queria terminar o dia fazendo massagem, pois se dizia cansada e, então, fomos os três, para um spa típico chinês na volta para Shenzhen. Tentei evitar até o último minuto que aquilo acontecesse, mas Feifei pedia insistentemente a Shang, que pagou toda a conta da luxuosa casa de massagem. Informei que os esperaria no saguão e eles disseram que era melhor eu entrar, pois poderia demorar horas. Eu achava que não havia sentido em acabar o dia numa banheira de hidromassagem. Aquilo soava intimista demais diante de um informante que, ao longo do dia, se comportara muito formalmente.

Dentro do spa, passei boa parte da noite aguardando e seguindo Feifei e, de vez em quando, encontrava Shang, meu informante, de roupão e acenava para ele. Lá dentro, nas piscinas, sob massagens e tratamentos estéticos, a sensação era a mais estranha possível. De roupão, cochilando, eu sentava e aguardava Feifei cansar, mas ela era incansável. Ela, mais uma vez, saía lucrando em dinheiro e serviços. Para mim, Shang era um informante em potencial; para ela, um doador de bens, graças ao prestígio que ela possuía junto ao policial.

Cheguei em Hong Kong quase de manhã. No outro dia, Shang telefonou-me e pediu que eu fizesse umas fotos como modelo de sua marca de vinhos. Ele me pagaria RMB 5000. Eu prontamente aceitei e disse que não cobraria nada, pois seria "uma honra poder retribuir a gentileza do dia anterior", achando que esta era uma forma de retribuir o fato de ele ter passado um dia inteiro dirigindo pela província para que eu conhecesse uma fábrica e, além disso, agraciar-me com um spa ao final da noite. Achei que estaria jogando as regras de reciprocidade do guanxi. Ele, porém, disse-me com muita franqueza:

Se não quiseres dinheiro, tudo bem, mas eu não te ajudei. Eu ajudei o policial que me fez um pedido e eu não pude recusar. Gao estava fazendo um favor a Feifei porque ele é grato ao pai dela. O que eu fiz foi para Gao e não para ti. Agradeça a Feifei.

Diante disso, recusei a oferta e não procurei mais por Shang. 


\section{Entre empresários estrangeiros}

Feifei tinha alunos italianos e proprietários de uma fábrica em Ping $\mathrm{Hu}$ (perto de Shenzhen), que era terceirizada para as principais grifes italianas. Trata-se da empresa que produz mercadorias para Dolce \& Gabanna, Jeans Armani, Benetton, Sisley, entre outras importantes marcas italianas.

Quando eles se estabeleceram na China, às cegas (como muitos empresários estrangeiros que tentam prosperar naquele país), precisaram de muitos contatos, ou seja, precisaram forjar guanxi. Feifei, prontamente, acionou seus contatos de norte a sul do país, especialmente para Marcello o sócio mais jovem do grupo - para quem encontrou apartamento em Hong Kong, apresentou-o a empresários renomados de Xangai, e também a algumas amigas para que ele pudesse namorar. Ela, em troca, esperava ganhar mercadorias das fábricas, além de aumentar o prestígio de seu variado capital social.

Feifei, sabendo que eu estava interessada justamente nesse ramo da indústria da China, bem como pela questão das marcas em especial, colocoume em contato com eles, o que demorou algumas semanas, pois ela queria sempre "preparar" a situação. Na realidade, Feifei sabia que aquele contato era importante e tinha que valorizá-lo.

Fomos ao primeiro encontro na sede da empresa em Hong Kong e ela, novamente, apresentou-me como doutora, autora etc. Como estrangeira e de fenótipo ocidental, eu tinha alguns atributos que igualmente eram capitalizados por ela. Era interessante mostrar-se como alguém que detinha amizades estrangeiras (seja para os chineses, seja para os estrangeiros), o que lhe dava um aspecto de pessoa moderna e cosmopolita, como ela mesma dizia.

Eu considerei a ocasião formal, na medida em que conheceria empresários renomados do circuito da moda internacional. Minha fala pausada e acompanhada de sorrisos moderados e tímidos foi abruptamente contrastada com a frase introdutória de Feifei: "Ela é solteira, você é solteiro...!". Eu dizia para eles que aqueles comentários não faziam sentido algum. Feifei, por seu turno, também não se encontrava relaxada, mas extremamente tensa de permanecer naquele escritório, da mesma forma como estava no banquete. O assunto que ela desenvolvia não era fruto de sua descontração, mas vinha à tona na medida em que ela colocava intimidade em ambiente onde, para mim, não deveria haver

A conversa fluiu, direcionando-se para uma entrevista formal. Posteriormente, pedi para visitar as fábricas e realizar entrevistas e, para tanto, perguntei o e-mail dos sócios. Feifei imediatamente disse que isto não era preciso, pois ela mediaria os contatos, mas saí do encontro com o cartão de visita e a sensação de liberdade de quem, enfim, poderia negociar em língua 
inglesa e sem tanto autocontrole. A linguagem me libertava. Feifei, sempre que podia, fazia questão de ressaltar o quanto era bem relacionada. Como, neste caso, tratava-se de estrangeiros, tentei por mim mesma estabelecer os contatos e pude perceber o quanto isto a incomodava; tentava controlar a situação, mantendo-a sempre sob seu poder para demarcar sua centralidade e fazer-me dependente e endividada com ela.

Com o grupo de italianos a relação etnográfica foi completamente diferente. A maior parte das visitas às fábricas e das entrevistas aconteceu sem Feifei e de acordo com o que eu considerava o habitual de uma etnografia: acompanhamento direto de eventos de trabalho e social, entrevistas formais e informais etc. A facilidade de comunicação com essa rede não residia somente na linguagem, visto que a determinada altura eu já tinha um mandarim fluente, mas meus relacionamentos com chineses não avançavam além do circuito da escola de língua. Essa diferença na acessibilidade de redes de informantes mostrava que, para consolidar circuitos de relacionamentos locais, era preciso base, confiança, tempo, interesse mútuo e sentimentos compartilhados.

\section{Refletindo sobre guanxi: limites, temporalidades, regras, poderes...}

\section{Intimidade e economia}

Intimidade e economia possuem falsas fronteiras, como bem pontuou Viviana Zelizer. A prática do guanxi une o que o Ocidente apartou, ao crer que "intimidade corrompe a economia e a economia corrompe a intimidade" ou, mais explicitamente, "[crê-se que] a atividade econômica degrada os relacionamentos íntimos, enquanto a intimidade interpessoal torna a atividade econômica ineficiente" (Zelizer 2005:01). Esse dualismo não existe somente nas análises econômicas neoclássicas, mas também está imbuído no senso comum e nas práticas cotidianas.

De fato, a forma como foi conduzida a etnografia entre estrangeiros e chineses ilustra esse processo; no momento em que, entre os empresários italianos, sociabilidade lúdica e pesquisa de campo pareciam ocorrer em espaços simbólicos diferenciados, isto não ocorreu da mesma forma com os empresários chineses. As regras de conduta e o formalismo eram diferentes.

Como estrangeira, ao mesmo tempo em que era muito mais difícil acessar um circuito de relacionamento, os rituais de agregação eram bem mais complexos e intimistas entre os informantes chineses. Já entre o grupo de italianos, embora o contato inicial tenha ocorrido de forma muito mais fácil e espontânea, o desenvolvimento das relações era mais impessoal e 
profissional, ainda que com esse grupo eu também tenha compartilhado momentos lúdicos, mas estes vivenciados como um espaço à parte da pesquisa. Desse modo, fica claro que, entre os eventos apresentados, estavam em jogo diferentes visões de mundo acerca dos negócios e da intimidade, da vida pública e da privada. A minha própria participação nesses dois universos de negócios ilustra isto, pois ainda que houvesse intimidade em ambas as situações, as formas de conduzi-la eram diferentes.

No contexto de pesquisa com os chineses, negócio, intimidade e sociabilidade aconteciam nos mesmos eventos - o que é relativamente comum em muitos países do extremo Oriente. As fronteiras tênues entre vida pública e privada e a forma com que o pessoal convive com o impessoal e o racional o econômico - foram percebidas primeiramente através de meu contrato com Feifei, no momento em que eu concebia entrevistas livres de beijos, bem como saídas de campo sem paradas em casas de massagens. No entanto, os interlocutores raramente pensavam diferente. Assim, a primeira lição que eu tive sobre algo amplo como a noção de "negócio chinês" aconteceu quando eu mesma tornei-me ator econômico, tendo expectativas sobre meus próprios contratos e acordos. Somente então pude alcançar um segundo nível, qual seja, o entendimento das trocas mercantis que ocorrem entre os empresários no universo empírico e o papel das relações pessoais nesse contexto. Assim consegui entender, por exemplo, por que aquele almoço com Gao e os empresários era considerado uma reunião de negócios sem, contudo, ter-se falado um minuto sequer sobre o assunto, mas antes sobre bebidas, amenidades e jocosidades. Como lembra Wank (1996), o tempo dispensado em um banquete acaba por deslocar a essência da instrumentalidade para a intimidade.

Por essas razões, estrangeiros que possuem interesse em investir na China frequentemente necessitam ser iniciados na arte de guanxixue, uma vez que negócios não prescindem da intimidade; ao contrário, o relacionamento próximo é que traz a confiança. Acordos, certamente, são mais baseados em bebidas e comidas do que em letras microscópicas escritas num contrato. Como pontua Zelizer (2005), intimidade e economia são atividades complementares, e a primeira, muitas vezes, organiza a segunda que, por sua vez, cria, mantém e renegocia importantes laços pessoais ao estabelecer obrigações e direitos entre os participantes.

\section{Tempo e restrições}

Através da exposição do primeiro caso, meu objetivo foi mostrar que estabelecer guanxi demanda um tempo próprio que não é o do imediatismo, 
mas o do cultivo, do desfrute e também do prazer. Ademais, o primeiro e o segundo juntos demonstraram que os atores envolvidos não tinham qualquer interesse em estabelecer conexão comigo, pois isto fere alguns princípios do guanxi: a quantidade limitada de laços, a falta de base e o benefício mútuo.

Em primeiro lugar, diz-se, no discurso popular, que é aconselhável possuir um número limitado (mas eficiente) de conexões para não ficar em débito com muitas pessoas. Portanto, não se faz guanxi com qualquer pessoa. Como já foi dito, eu e Feifei não estabelecemos laço aleatoriamente, mas sim a partir de nossa base anterior, advinda da relação professor/aluno - uma das bases mais valorizadas. Tínhamos expectativas mútuas, como a troca de serviços por dinheiro, bem como a amizade fruto de pertencermos a uma mesma geração. Naquela relação o interesse não era sublimado.

Eu, na condição de pesquisadora, invariavelmente não tinha nada a oferecer àqueles empresários e aos jovens empreendedores. Por mais que a cordialidade marcasse aquele encontro, sabia que se precisasse de algum deles posteriormente, esbarraria em uma série de empecilhos. Conforme as duras palavras de Feifei:

Ninguém vai te abrir uma porta, por mais que eu fique inventando que você é rica, conhece pessoas importantes e é doutora. Eles olham para você e veem uma brasileira, eles nem sabem onde fica o Brasil no mapa... Por que vão abrir o mundo deles para você? O que eles querem com o Brasil? Você mesmo viu, já te apresentei dezenas de pessoas e quantas delas falam inglês? Nem por inglês eles se interessam.

Tudo passa por mim, não se iluda. Nós duas temos guanxi porque somos jovens, mulheres e você é minha aluna. Tenho guanxi com Hui e Gao por outras razões.

Estas palavras possuíam um fundo de realismo. É evidente que, além do pragmatismo que evoca, há o fato de que Feifei desejava manter-me dependente dela, permanecendo como elemento centralizador, da mesma forma como as relações na China não são estreitas e engessadas. Seus contatos constituíam sua moeda de troca. Assim como os capitalizava para me deter, usava a minha companhia para se promover para os outros. O que ela tinha de mais precioso era seu capital social, que negociava ao converter em outros capitais.

Todavia, apesar de eu não ter estabelecido guanxi diretamente com nenhum dos membros das redes, é importante atentar para a facilidade com que acessei uma fábrica através do contato com o policial. Um enorme esforço etnográfico se desfez num instante pelo poder da burocracia estatal encarnada na figura de um de seus agentes, que tinha muito claro o peso dos favores e que sabia se beneficiar muito bem deles. 


\section{Karaokê, cigarros e homens de negócios}

Nas duas primeiras redes apresentadas, tratava-se de "homens de sucesso", representativos das novas classes sociais que emergiram a partir da expansão da região do Delta. A ritualização de cada caso variava de acordo com o status econômico das pessoas envolvidas, bem como através das diferenças de geração: jovens tinham a sua forma de celebrar a comilança e a bebedeira no karaokê, enquanto os mais velhos e ricos não dispensavam o banquete tradicional. A pompa e a etiqueta variavam nos diferentes eventos, mas conservavam a matriz de significado, uma vez que karaokês, na China atual, representam uma continuidade dos banquetes, ao ocorrerem em salas privadas de restaurantes que acomodam um pequeno grupo de pessoas, mantêm uma relação com a hospitalidade caseira e conferem ao evento um espírito de proximidade e intimidade, ao beberem e cantarem juntos. É importante lembrar que muito daquilo que se concebe como "investimento" também é construído sob doses cavalares de ganbei (brinde), ou melhor, beber é o investimento em si.

Misturar negócios com banquetes, bebidas e mais recentemente com karaokê é uma antiga tradição em Taiwan. A maioria das pequenas empresas considera isso um importante aspecto no ato de fazer negócios. [...]. Karaokês são encontros importantes e estabelecem relações de confiança. [Um informante disse:] "Quando você bebe com alguém, você reduz a distância entre as pessoas" (Shack 2000:121).

O papel da masculinidade é outro fato notável. Ser empresário "de sucesso", ou seja, ser patrão, ter dinheiro e poder, é uma esfera muito mais restrita aos homens. Ao longo do processo de pesquisa, foram poucas as mulheres que conheci que eram laoban (patroa). A "corrida empresarial" que existe na região do Delta parece obedecer a um recorte de gênero, pois atualiza certos papéis masculinos, como o de provedor. Na condição de mulher, jamais pude contribuir com qualquer centavo em refeições, passeios ou outro evento. No entanto, estava consciente das consequências e das indesejadas ofertas às quais estava sujeita no momento em que aceitava as dádivas.

Todos os empreendedores chineses fumavam demasiadamente nas mais diversas ocasiões das quais participei. O papel dos cigarros caros nas demonstrações de poder masculino é crucial e constitui, nos termos de Bourdieu (2000), um capital simbólico objetivado. Como mostra Wank (2000), trata-se de um bem singular que atualiza desigualdades sociais, devido à carga de poder que ele representa no dia a dia. Para alcançar a dimensão do que esse 
poder significa, é preciso entender a ênfase que o cigarro adquire na China em tempos de abertura econômica, na medida em que, no passado recente, tratava-se de um bem de luxo escasso, que só era alcançado via guanxi com o poder oficial. Como assinala o autor, por muito tempo homens fumaram não apenas por prazer, mas pelo valor de troca que essa mercadoria tinha. Com a abertura econômica, esse luxo se disseminou ao alcance de muitos, mas alguns ainda continuam extremamente valiosos e são usados como importante moeda de troca entre empresários.

Em negociações, compartilhar o fumo é parte do evento, tanto como comer e beber. Enquanto os jovens do karaokê fumavam cigarros mais comuns e baratos, no banquete todos os participantes deixavam uma carteira de cigarros nobres sobre a mesa. Gao exibia (e consumia muito) duas carteiras da marca Chunghwa, cujo preço é de 400 yuan (aproximadamente $R \$ 100$ ). Trata-se de um cigarro paradigmático na China, que traz na embalagem a imagem da Cidade Proibida. Durante a Revolução Cultural, a empresa foi estatizada, passando a produzir apenas para a cúpula do PCC. Era, notoriamente, a marca preferida de Mao Tse-tung. O que podemos perceber, enfim, é que não se traga apenas nicotina, mas fundamentalmente uma forte simbologia de poder e status.

\section{Banquetes, propinas e clientelismo}

No segundo caso apresentado, havia um personagem central: Gao. Naquela ocasião ficou explícito o papel do policial em seu entourage. Ele era um agente de posto médio, mas bem relacionado com autoridades de várias províncias e diversos status. Alguns pesquisadores entendem que guanxi com um baixo funcionário é mais útil por eles serem mais disponíveis (Yang 1994), enquanto outros consideram irrelevante cultivar relacionamento com pessoas de pouco poder; importante seria relacionar-se com os altos quadros, que possuem, de fato, poder de decisão (Gold 1985; Smart 1993).

Na realidade, a importância é dada pelo contexto e pelo acesso que cada um tem a bens e serviços. Gao era alguém estrategicamente posicionado e a fortuna que alcançara, em seus 35 anos de idade, deixava isto evidente. Além dos inúmeros presentes que ganhou naquele evento, ofereceram-lhe também o banquete. O poder que ele detinha era expressivo, capaz de movimentar executivos de grandes empresas.

Para Yang (1994), banquetes fazem parte de uma economia do dom. Aquele que oferece um banquete torna-se superior moralmente e forma-se uma hierarquia, fruto do ciclo do dom. Mas isto se torna particularmente 
interessante quando o "doador" ocupa uma posição inferior ao receptor (empresários detêm o capital econômico, mas são os agentes do Estado, em última instância, que possuem o poder de decisão), fazendo com que a subordinação momentaneamente se inverta. Naquela ocasião, todos ressaltavam a importância de estarem ligados a um funcionário estatal e cuidavam dessa relação através de presentes, não como quem oferece propina, mas como quem se resguarda para o futuro.

Ainda que o poder dos oficiais continue soberano, houve uma inversão no que se refere à distribuição de bens raros e escassos. Nos tempos da Revolução Cultural, ofereciam-se banquetes às autoridades em troca de cigarros, bebidas, comidas, remédios. Hoje, são os agentes do governo que recebem tais produtos ao possuírem menos capital econômico do que os empresários. Eles continuam sendo agraciados com banquetes, mas também com outros presentes materiais, como no caso de Gao, com chás raros e bebidas caras. Entretanto, existia alguém invisível e mais poderoso em toda aquela rede (guanxiwang) - o pai de Feifei, general do exército chinês. O policial, ao encher o porta-malas com seus presentes, tratou de separar as melhores especiarias e repassar para seu antigo apoiador. Na realidade, embora o doador de mercadorias se tenha invertido na China atual, os instrumentos de dominação das autoridades mudaram apenas de tom e não de importância. Hoje, eles redistribuem poder simbólico.

Naquele evento, o banquete materializava o guanxi. Os interesses e os ganhos são suavizados nesse universo de dádivas a longo prazo e, por isso, não se constituem como propina. Assim, os favores alcançados entre empresários e autoridades são classificados como fruto da amizade e seguem a lógica da antiga busca por shouren: pessoa familiar influente capaz de alocar objetos ou favores desejáveis devido à posição que ocupa. Shouren pode variar do patriarca na família que tem poder de convencimento ao alto quadro do Estado, que disponibiliza recursos (Yang 1994).

Entendo que, embora guanxi e corrupção possam eventualmente se aproximar, não se trata de sinônimos. Para os chineses, corrupção não exige a formação de um vínculo afetivo, tratando-se, portanto, de uma negociação considerada fria. Shang e Xin, por exemplo, contaram-me que conseguem sobreviver na cena mercantil através da sonegação de impostos via "boa vontade da gaveta", como eles assim denominavam, ou seja, se colaborassem com autoridades locais, metaforicamente colocando bens na gaveta, portas se abriam. Hui também afirmava que a propina entre agentes locais e fabricantes era muito forte, principalmente no interior do país, fato este que acaba alicerçando a manutenção do comércio ilícito (como a falsificação), a disseminação de fábricas e o crescimento vultoso de micros e médios 
empresários. Mas esse tipo de prática não necessitava de vínculo, muito menos de banquetes.

Sobre os limites de guanxi e corrupção, vale a pena pensar um pouco mais sobre o exemplo de Gao. Ele recebia seus presentes de antigos conhecidos que ajudava e com os quais possuía forte renqing (sentimento). As lembranças, as risadas, a intimidade da conversa e os presentes deixavam isto bastante claro. No entanto, essa forma de relacionamento singularmente estreito fez igualmente com que Gao enriquecesse rapidamente e alcançasse um patrimônio de 1 milhão de yuan. Nessas alianças, o que diferencia guanxi de corrupção e propina é, basicamente, a forma como as trocas são realizadas: em momentos adequados e rituais públicos, espaçadas em longo prazo, sem nexo causal imediato entre uma dádiva e outra. Se a ilegalidade existe, ela torna-se imperceptível. Segundo Smart (1993), a diferença encontra-se na forma como o presente é doado e, reside, portanto, na intenção do doador, tratando-se de uma economia do dom que, nesses casos, fortalece e complementa a instabilidade do mercado.

No banquete do qual participei, os empresários, ao doarem bebida, chá, porcelana e refeição ao policial, ganhavam mianzi (prestígio) com ele a longo prazo. Ao contrário, propinas, que são esporádicas, não conferem capital social nem simbólico. Além disso, na situação mencionada acima, estavam sendo trocados bens adequados a uma etiqueta em um determinado ritual; tudo isto cria um ambiente que os protege de virem a ser acusados de corruptos, no momento em que o próprio aceite implica grande modéstia. Quando um empresário entregou um presente ao policial na ocasião do banquete, o receptor aceitou a dádiva recuando e, ao mesmo tempo, sorrindo levemente de cabeça baixa, dizia não ser merecedor. O aceite veio através da insistência do doador. Tudo era feito de forma pública e aberta.

Os agrados que o policial ganhou naquele almoço chocariam muitos não chineses. No entanto, não creio que tais dádivas se diferenciem significativamente do presente que eu mesma levei a Hui quando queria lhe pedir uma entrevista, ou do próprio pagamento a Feifei por horas (não) traduzidas. O retorno é esperado, mas nem sempre implica ilegalidade.

Segundo Wank (1996), esses laços clientelistas foram difundidos na era pós-Mao, constituindo-se em uma ação desviante do mercado e da política central, e apontam a permanência da dependência do oficialismo e das relações verticais entre quadros do governo e da sociedade. Paradoxalmente, através de alianças entre autoridades e empresários, trata-se de um meio de proteger o mercado das mudanças abruptas do plano político e econômico central.

Uma vez que propinas são esporádicas e privadas e dádivas são contínuas e acontecem em cerimoniais públicos, essas formas de guanxi e clientelismo 
acabam sendo institucionalizadas no país e não é exagero dizer que sustentam boa parte do desenvolvimento econômico e da industrialização do Delta e da China. Trocas impessoais dão o tom de um desenvolvimento singular que muda muito pouco o sentido do poder de sua estrutura burocrática.

O poder de Gao sobre pequenos e grandes empresários (de empresas nacionais ou mistas) e o simplório enfeite giratório de seu carro, que ora mostrava a cara de Mao, ora a de Marx, dizem-nos muito sobre o período da transição, ou melhor, versam sobre a forte presença e o controle do Estado, da burocracia sobre a economia e da importância de manter-se ligado ao governo. A camaradagem almejada no nível do discurso partidário cede lugar à prática dos laços particularistas.

\section{La guanxi: guanxi "boa" para lucrar}

Como os banquetes constituem uma importante tática de estabelecer guanxi, multiplicam-se, no mundo todo, livros da área de negócios que ensinam a um empresário como deve oferecer banquete numa negociação com chineses. Esses livros dizem o que oferecer, como se portar, se se deve ou não aceitar os ganbei, o que falar, como falar e, sobretudo, alertam para o perigo de uma gafe e o quanto isto pode colocar tudo a perder. ${ }^{6}$

Não cabe aqui discutir a relevância de tais livros e manuais. É importante apenas perceber o quanto um elemento êmico da cultura chinesa é usado para promover uma "fórmula de sucesso". Tais publicações trabalham com representações sobre o mundo de negócios na China globalizada e o reconhecimento de que isso passa por antigos cerimoniais de regras bem definidas. A ideia que está por trás disso é de que "sem guanxi seu negócio não prosperará". No entanto, estabelecer e cultivar o guanxi é, antes de uma estratégia de mercado de acesso universalista, um sistema cultural complexo, particularista e exclusivo.

O modo sui generis do capitalismo chinês, especialmente expresso na formação e na manutenção do guanxi, nos aponta uma ambivalência. Por um lado, o sistema mundial capitalista, para Sahlins (2004), "pôs-se à solta" mundo afora, porém foi incapaz de destruir as culturas periféricas, tendo que se adaptar a sistemas simbólicos locais. A economia de mercado não acabou com a cultura chinesa; ao contrário, teve de se adaptar a um sistema simbólico singular, que supervaloriza as relações pessoais. Por outro lado, também é verdade que o acionamento de elementos culturais locais no âmbito das negociações contemporâneas pode ter um uso bastante pragmático, fazendo da cultura uma estratégia racional de otimização do capital. Esta foi a maneira que o capital estrangeiro encontrou para se expandir na China. 
Como já ressaltei, abundam exemplos de publicações que exaltam a importância do guanxi para o sucesso na China, estabelecido não apenas com autoridades, mas com os próprios empregados da empresa. Esses livros narram desde o estabelecimento da Coca-Cola até a "saga de Gates" e da Microsoft na China. Diretores-executivos de empresas como Airbus, Bayer, Coca-Cola, GE, GM, Philips, Microsoft, Siemens e Sony são igualmente unânimes em afirmar que nada é mais fundamental do que guanxi ("bom" e não a corrupção) para se vencer na China, conforme demonstrado num estudo realizado por Fernandez e Underwood (2006).

Assim, estrangeiros na China se utilizam desse elemento cultural com vistas à obtenção de lucro, cooptação de empregados, mas principalmente redução do tempo de burocracia. No Brasil, empresários que comercializam com aquele país frequentemente realizam palestras sobre a importância dos laços e são muitos os que mantêm firmas de mediação de negócios, oferecendo, sobretudo, capital social no país de investimento.

Os informantes de Smart (1993), por exemplo, na tentativa de realizarem joint ventures, relataram que, através das etiquetas do guanxi, um processo que levaria anos pode ser adiantado em três meses, se construído com cigarros e banquetes. O mesmo me disse Marcello, o sócio da empresa que fabrica bolsas de grifes italianas, sobre a importância de se manter contato com as autoridades locais para conseguir alugar, em um curto espaço de tempo, um prédio em Shenzhen.

Desse modo, o guanxi não é apenas importante para os informantes contatados, nem somente para pequenos e médios empresários chineses, os quais seriam dependentes de autoridades locais, em contraposição a um suposto mundo da "legalidade" das empresas multi e transnacionais, que se caracterizariam pela impessoalidade, a racionalização, a autonomia em relação ao Estado, a formalidade e o cosmopolitismo. A variável cultural é também forjada para alcançar fins práticos, na medida em que há um reconhecimento generalizado de que a ética afetiva do guanxi é também uma ética efetiva.

\section{Considerações finais}

Este artigo discutiu a importância do guanxi no processo de abertura econômica da China, a partir do entendimento da ação cotidiana de atores que produzem uma dialética constante entre transformação e reprodução da realidade social. Noutras palavras, o guanxi é uma prática simbólica da sociedade chinesa que, assim como indigeniza o capitalismo - introdu- 
zindo elementos locais nas trocas econômicas e desenvolvendo uma forma particular de realizar os negócios - é igualmente transformada por ele, adaptando-se às demandas de uma economia de mercado, a qual incentiva o consumo e a obtenção de lucro privado.

A etnografia apontou três camadas interpretativas relacionadas à importância da arte do relacionamento social na China, em sua dimensão material e imaterial, afetiva e pragmática. A primeira refere-se à minha própria prática etnográfica, no momento em que eu mesma estabeleci guanxi com Feifei, tornando-me também um agente econômico. Nossa relação nascia da base professor/aluno e estava pautada por interesses e sentimentos mútuos. No entanto, nossas trocas evidenciavam que havia duas visões de mundo conflitantes acerca dos negócios e das formas de se conduzir e cumprir um acordo.

A segunda camada refere-se aos informantes entre si - comerciantes, empresários e autoridades - e como a etiqueta do relacionamento tem sido atualizada em tempos de grande mudança social. Nos eventos observados, os presentes - cigarros, chás, comidas e bebidas - que são parte fundamental dos circuitos de dádivas, eram acionados no intuito de manter elos afetivos, bem como de obter vantagens nas transações econômicas, as quais ainda se mantêm fortemente vinculadas ao Estado chinês e aos seus agentes. Desse modo, é possível avançar para uma dimensão mais ampla de análise e inferir que a importância dos laços pessoais se renova no contexto de mudança social - o que reforça a ideia de que a ultrarracionalidade do mercado é uma ilusão pragmática do Ocidente.

Tanto no que se refere ao mercado interno quanto ao externo, o guanxi aparece como um elemento nativo centralizador, desempenhando o papel de consolidador das trocas mercantis, mas não apenas isto. Embora as publicações sobre negócios internacionais alertem para a necessidade de forjar laços para obter lucros na China, sabemos que uma perspectiva antropológica sugere justamente o contrário: as trocas são um meio para consolidar vínculos humanos.

Os eventos etnográficos ilustraram os mecanismos de inclusão, manutenção ou exclusão de sujeitos e redes mercantis em um processo de abertura que ruma para uma economia de mercado globalizada, mas que, concomitantemente, mantém traços culturais locais. Seguindo uma tendência da antropologia contemporânea, a de romper com dicotomias que a própria tradição ocidental da disciplina criou (dom e mercadoria, interesse e sentimento, público e privado etc.), discorri sobre sujeitos, poderes e bens a partir da descrição da dimensão mais íntima do universo do relacionamento social, no intuito, enfim, de refletir sobre o complexo encontro do Estado e do mercado e a forma como o capitalismo - aliado a um idioma nativo de trocas, presentes, sentimentos, etiquetas e emoções - encontra lugar na China pós-Mao. 
Rosana Pinheiro-Machado é professora e pesquisadora da Escola Superior de Propaganda e Marketing — ESPM-Sul. E-mail: <rmachado@espm.br>

\section{Notas}

· Uma versão embrionária deste artigo foi apresentada no Seminário Temático de Sociologia Econômica no encontro da ANPOCS de 2007. Agradeço a todos os participantes e aos(as) coordenadores(as) do grupo por suas valiosas contribuições. Agradeço também a Ruben Oliven pelo incentivo constante e aos pareceristas anônimos da Revista Mana, que trouxeram colaborações decisivas para a melhoria da versão final deste artigo.

${ }^{1}$ De fato, as reformas começaram em dezembro de 1978 e, portanto, o processo de abertura é datado de 1979.

${ }^{2}$ Fonte dos dados: <http://www.gprd.com.br>

${ }^{3}$ Todos os nomes foram alterados.

${ }^{4}$ Esses autores apontados anteriormente - mesmo entendendo o papel das redes como vital para o capitalismo (ao contrário do que inferiu Weber) — seguem, direta ou indiretamente, uma linha weberiana de pensamento social, utilizando-se das noções de burocracia, racionalização dos indivíduos e religião e ethos capitalista.

${ }^{5}$ Expressão citada por Thomas Gold durante uma conferência sediada em Berkeley, em 1998.

${ }^{6}$ Há, inclusive, livros de versões de bolso ilustradas, tais como o título Chinese business etiquette: the practical pocket guide. 


\section{Referências bibliográficas}

APPADURAI, Ajurn. 2006. "Introduction: commodities and the politics of value". In: A. Appadurai (org.), The social life of things. Commodities in cultural perspective. Cambridge: Cambridge University Press. pp. 3-63.

BOURDIEU, Pierre. 2000. O poder simbólico. Rio de Janeiro: Bertrand Brasil. 2001. "The forms of capital". In: M. Granovetter \& R. Swedberg (orgs.), The sociology of economic life. Boulder: Westview Press. pp. 96-111.

CHAN, Kwok Bun (org.). 2000. Chinese business networks. State, economy and culture. Singapore: Prentice Hall.

COLLINS, Randall. 1999. Weberian sociological theory. Cambridge: Cambridge University Press.

DAVIS, Deborah (org.). 2000. The consumer revolution in urban China. London: University of California Press.

DELAUNE, Florence. 1998. Entreprises familiales chinoises en Malaisie. Villeneuve D'ascq: Presse Universitaire du Septentrion.

FERNANDEZ, Juan \& UNDERWOOD, Laurie. 2006. China CEO. Singapore: John Wiley \& Sons.

FREEDMAN, Maurice. 1967. "Immigrants and associations. Chinese in nineteenth-century Singapore". In: L. Fallers (org.), Immigrants and associations. Paris: Mouton. pp. 17-48.

GIPOULOUX, François. 2000. "Networks and guanxi: towards an informal integration through common business practices in greater China". In: K. B. Chan (org.), Chinese business networks. State, economy and culture. Singapore: Prentice Hall. pp. 57-70. GOLD, Thomas. 1985. "After comradeship: personal relations in China since the Cultural Revolution". The China Quarterly, 104:657-675.

GOLD, Thomas; GUThrie, Doug \& WANK, David (orgs). 2002. Social connections in China. Cambridge: Cambridge University Press.

GRANOVETTER, Mark. 1973. "The strength of weak ties". American Journal of Sociology, 78:1360-80. 1974. Getting a job. Cambridge, MA: Harvard University Press.

GUTHRIE, Doug. 2002. "Information asymmetries and problem of perception". In: T. Gold; D. Guthrie \& D. Wank (orgs.), Social connections in China. Cambridge: Cambridge University Press. pp. 37-56.

HWANG, Kwang-Kuo. 1987. "Face and favor: the chinese power game". The American Journal of Sociology, 92(4):944-974.

JACOBS, Bruce. 1979. "A preliminary model of particularistic ties in chinese political alliances: Kan-ch'ing and Kuan-hsi in a rural taiwanese township". The China Quarterly, 78:237-273.

KIPNIS, Andrew B. 1996. "The language of gifts: managing guanxi in a north China village". Modern China, $22(3): 285-314$.

. 1997. Producing guanxi: sentiment, self and subculture in a north China village. Durham: Duke University Press.

LI, Cheng. 2000. '“Credentialism' versus 'entrepreneurism'". In: K. B. Chan (org.), Chinese business networks. State, economy and culture. Singapore: Prentice Hall. pp. 86-111.

LI, Peter. 2000. "Overseas chinese networks: a reassessment". In: K. B. Chan (org.), Chinese business networks. State, economy and cul- 
ture. Singapore: Prentice Hall. pp. 261-284.

MACKIE, Jamie. 2000. "The economic roles of the southeast asian chinese". In: K. B. Chan (org.), Chinese business networks. State, economy and culture. Singapore: Prentice Hall. pp. 234-260.

MAMUNG, Emmanuel. 2000. La diaspora chinoise: géographie d'une migration. Paris: GéOphrys.

MAUSS, Marcel. 2003. "Ensaio sobre a dádiva: forma e razão da troca nas sociedades arcaicas". In: Sociologia e antropologia. São Paulo: Cosac \& Naify. pp.185-318.

NEE, Victor. 1989. "A theory of market transition: from redistribution to markets in state". American Sociological Review, 54(5):663-681

. 1992. "Organizational dynamics of market transition: hybrid forms, property rights, and mixed economy in China". Administrative Science Quarterly, 37(1):1-27.

OI, Jean. 1985. "Communism and clientelism: rural politics in China". World Politics, 37(2):238-266.

ONG, A. \& LI, Z. (orgs.). 2008. Privatizing China. Ithaca and London: Cornell University Press.

OXFELD, Ellen. 1992. "Individualism, holism, and the market mentality: notes on the recollections of a chinese entrepreneur". Cultural Anthropolo$g y, 7(3): 267-300$.

PINHEIRO-MACHADO, Rosana. 2007. "A ética confucionista e o espírito do capitalismo". Horizontes Antropológicos, 28:145-174. . 2009. Made in China. Produção e circulação de mercadorias no circuito China-Paraguai-Brasil. Tese de Doutorado. Universidade Federal do Rio Grande do Sul.

REDDING, S. Gordan. 1993. The spirit of chinese capitalism. Berlin, New York: Walter de Gruyter.
SAHLINS, Marshall. 1985. Islands of history. Chicago: The University of Chicago Press. 2004. "Cosmologias do capitalismo. O setor transpacífico do sistema mundial". In: Cultura na prática. Rio de Janeiro: Ed. UFRJ. pp. 445-502.

SHAK, David C. 2000. "Networks and their uses in the taiwanese society" In: K. B. Chan (org.), Chinese business networks. State, economy and culture. Singapore: Prentice Hall. pp. 112-129.

SMART, Allan. 1993. "Gifts, bribes, and guanxi: a reconsideration of Bourdieu's social". Cultural Anthropology, 8(3):388-408.

TAN, Chee-Beng. 2004. Chinese overseas, comparative cultural perspectives. Hong Kong: Hong Kong University Press.

VANGENNEP, Arnold. 1978. Os ritos de passagem. Petrópolis: Vozes.

VOGEL, Erza. 1965. "From friendship to comadership". The China Quarterly, 21:46-60.

WANK, David. 1996. "The institutional process of market clientelism: guanxi and private business in a south China city". The China Quarterly, 147:820-838.

2000. "Cigarettes and domination in chinese business networks". In: D. Davis (org.), The consumer revolution in urban China. London: University of California Press. pp. 268-286. 2002. "Business-state clientelism in China". In: T. Gold; D. Guthrie \& D. Wank (orgs.), Social connections in China. Cambridge: Cambridge University Press. pp. 97-116.

WEBER, Max. 1968. The religion of China. New York: A Free Press Paperback. 2004. A ética protestante e o espírito do capitalismo. São Paulo: Companhia das Letras.

WU, Wei-Ping. 2000. "Transaction cost, cultural values and chinese business 
network: an integrated approach" In: K. B. Chan (org.), Chinese business networks. State, economy and culture. Singapore: Prentice Hall. pp. 35-56. YAN, Yunxiang. 1996. The flow of gifts. Stanford: Stanford University Press. YANG, Mayair Mei-Hui. 1994. Gifts, favors \& banquets. London: Cornell Univiversity Press.

ZELIZER, Viviana. 2001. "Human values and the market". In: M. Granovetter \& R. Swedberg (orgs.), The sociology of economic life. Boulder: Westview Press. pp. 146-162.

2005. The purchase of intimacy. Princeton e Oxford: Princeton University Press. 


\section{Resumo}

Este artigo trata da importância das redes de relações pessoais no processo de abertura para a economia de mercado da China contemporânea. O sistema de guanxi, que significa conexões interpessoais de ajuda mútua, ao invés de desaparecer ao longo da reforma econômica, fortaleceu-se sobremaneira, constituindo-se como elemento êmico crucial para o desenvolvimento de negócios nas mais diversas esferas econômicas, locais e globais. Esse modo sui generis entrelaça autoridades do Estado e empresários, que são as novas elites do país, e atualiza antigos cerimoniais de dádivas. À luz do método etnográfico, discuto esse tema, apresentando três casos que representam meu processo de formação de guanxi durante trabalho de campo na Província de Guangdong.

Palavras-chave China, Guanxi, Dádiva, Capitalismo chinês, Etnografia

\section{Abstract}

The article discusses the importance of personal networks in opening up the contemporary Chinese economy to market forces. Instead of disappearing in the process of economic reform, the system of guanxi - a word signifying interpersonal connections based on mutual help - has actually strengthened hugely, becoming a crucial emic element in the development of business among the most diverse economic spheres, both local and global. This sui generis mode brings together authorities and business people - who form the country's new elite - and reproduces traditional gift ceremonies in new ways. Using an ethnographic methodology, zI discuss the topic through the presentation of three cases illustrating my process of making guanxi during fieldwork in Guangdong Province

Key words China, Guanxi, Gift, Chinese Capitalism, Ethnography 